\title{
Problem based learning and involvement in off campus organization enhance students' critical participation behavior
}

\author{
Endang Lestari \\ Faculty of Medicine, Sultan Agung Islamic University (UNISSULA), Semarang
}

\begin{abstract}
Abstrak
Tujuan Untuk mengidentifikai faktor-faktor dominan terhadap sikap partisipasi kritis mahasiswa FK Unissula dalam menyelesaikan masalah masyarakat.

Metode Subjek terdiri dari mhasiswa angkatan 2005, 2006 dan 2007. Sikap berfikir kritis diukur dengan menggunakan kuesioner modifikasi EMI: Critical Thinking Disposition Assessment. Untuk mengidentifikasi faktor-faktor risiko yang berhubungan dengan sikap partisipasi kritis mahasiswa dengan pendekatan risiko relatif (RR) yang dihitung dengan regresi Cox dengan time konstan dan menggunakan software STATA 9.

Hasil Sebanyak 64,6\% (388 dari 600) mahasiswa yang berpartisipasi dalam penelitian ini memilik sikap berpartisipasi baik menghadapi masalah masyarakat. Dibandingkan yang terpapar PBL 1 tahun, yang selama 2 tahun dan 3 tahun mempunyai kemungkinan bersikap partispasif dua kali lipat lebih baik [masing-masing risiko relatif $(R R)=2,07$; $95 \%$ interval kepercayaan $(C I)=1,37-3,14$; dan $R R=2,3395 \% C I=1,55-3,49)$. Mahasiswa yang terlibat dalam organisasi luar kampus dibandingkan yang tidak terlibat mempunyai kemungkinan 75\% lebih banyak bersikap partispasif baik $(R R=1,75 ; 95 \% C I=0,99-3,11)$.
\end{abstract}

Kesimpulan Untuk meningkatkan partisipasi kritis, selain terlibat dalam kegiatan pembelajaran dengan pendekatan PBL, mahasiswa perlu dibiasakan terlibat dalam kegiatan organisasi di luar kampus. (Med J Indones 2009; 18: 217-22)

\begin{abstract}
Aim Developing students' critical thinking and critical participation in solving patients' as well as a community's problem should become the concern of medical education. This study aimed to identify several factors related to medical students' critical participation behavior.

Methods The subjects consisted of students of Sultan Agung Medical School (Unissula), year entry 2005, 2006, and 2007. Critical participation behavior was assessed using modified EMI: Critical Thinking Disposition Assessment. Relative risks (RR) were calculated using Cox regression analysis with constant time.

Results $64,6 \%$ (388 out of 600) of the students participated in this study. Those who were involved in PBL for two and three years, rather than one year, had twice as high good critical thinking behavior [adjusted relative risk $(\mathrm{RR})=2.07$; $95 \%$ confidence interval $(\mathrm{CI})=1.37-3.14$; and $\mathrm{RR}=2.33 ; 95 \% \mathrm{CI}=155-3.49$, respectively.] Students who were more involved in off- campus organizations had a good critical participation behavior; $75 \%$ higher than those who were not involved in off-campus organizations $(\mathrm{RR}=1.75 ; 95 \% \mathrm{CI}=0.99-3.11)$.

Conclusion Besides involving in PBL learning approach, students should be motivated to be involved in off-campus organizations in order to improve their critical participation behavior (Med J Indones 2009; 18: 217-22)
\end{abstract}

Key words: critical participation behavior, $P B L$, off campus organization 
Critical thinking is a crucial aspect of the competence citizens need to participate in a plural and democratic society and to enable them to make their own contribution to that society. The Indonesian national standard competency based education, among others, states that the ability to critically solve problems should be one of the characters of an Indonesian Medical Doctor. ${ }^{1}$ Learning how to think and reason are main goals of education and teaching in higher education ${ }^{2}$ Some Indonesian medical schools teach critical thinking, clinical reasoning and problem solving. However, the literatures on the teaching and learning of critical thinking primarily focus on critical thinking as a higher-order cognitive skill rather than on critical thinking as a competence for critical participation in modern society. ${ }^{3}$ In his attempt to contribute to work out the issue, Ricketts ${ }^{4}$ developed the EMI Critical Thinking Disposition Assessment to evaluate engagement, maturity and innovation. Using the assessment, critical participation can be assessed based on the disposition of Engagement.

It is proven that Problem Based Learning (PBL) and an integrated curriculum can enhance a student's ability to think critically, improve higher order thinking ability, self directed learning, collaborative learning, teaching each other, deep learning, empathy and teach profesionalism. ${ }^{5}$ However, whether the approach can also enhance student critical participation should be evaluated. Besides, critical thinking disposition, including engagement, appears to be stable over a period of years, but yet there is space for significant growth. In her investigation of critical thinking dispositions, Rimiene reported that her investigation has corroborated this view. Some dispositions developed significantly while some remained unchanged. ${ }^{6}$ Considering that, it should be investigated as to whether critical participation behavior would develop.

Although the PBL approach and an integrated curriculum have been applied at Sultan Agung Medical Faculty since 2005, an evaluation of students' critical thinking skills and critical participation behavior has not been conducted. This study is aimed at investigating factors predicting medical students' critical participation behavior.

\section{METHODS}

The cross sectional study subjects consisted of Sultan Agung Islamic Medical Faculty year 1 up to year 3 students. Data collection was conducted from May until June of 2008.
Closed questionnaires were used to gather data about students' demographic data, such as age, gender, and entry year. Other questionnaires were applied to gather data about students' habits in accessing information from the internet, collaborative learning, reciting journals, as well as their involvement in off-campus and incampus organizations. The data was gathered after examinations. However, informed consent was provided to give students the option of taking part in the study.

Student critical engagement modified from Rickkets' EMI was used to explore student critical participation behavior. It consisted of 12 questions: (1) I look for opportunities to solve the community's problems; (2) I am interested in many community issues; (3) I am able to relate to a wide variety of community issues (4) I enjoy finding answers to challenging community questions; (5) I am a good problem solver; (6) I am confident that I can reach a reasonable solution to a community's problems; (7) I like to think things through; (8) I am able to apply my knowledge to a wide variety of community issues; (9) Good leaders listen to different opinions; (10) I am able to explain things clearly; (11) I ask good questions when trying to clarify a solution; (12) I present community issues in a clear and precise manner. For each questions the score ranged from 1 to 5 . The total score was divided into good critical participation behavior (scored 31 to 50) and fair critical participation behavior (scored 0 to 30 ).

Some risk factors which likely related to critical participation behavior collected: gender (male/female); age (17 -21years/22-24 years); duration of involvement in PBL curriculum (1, 2, 3 years); achievement score on critical thinking module (failed/fair/good/excellent); collaborative learning habit per week (never/1-3 times / $\geq 4$ times); starting habit for collaborative learning (never/few months ago/medical school/senior high school); involvement in off-campus organizations (no/yes), position in off-campus organizations (not involved/member/ section/ principals); leadership training (none/yes).

Relative risks (RR) was used to identify the risk factors related to students' critical participation behavior using constant time Cox regression ${ }^{7}$ analysis with STATA 10 program. A risk factor was considered to be a potential confounder, if the univariate test had a P-value less than 0.25 , and would be considered as a candidate for the multivariate analysis for good critical participation behavior.8 The Ethical Committee of the Faculty of Medicine of the UNISSULA approved this study. 


\section{RESULTS}

Three hundred eighty eight out of a total of 600 students $(64.6 \%)$ took part in this study. Scores ranged from 24 to 60 . Table 1 shows that $40.9 \%$ of the students had good critical participation behavior in community problem solving.

Table 1 indicates that students who had fair and good critical participation behavior were similarly distributed with respect to gender, Learning Skill and Critical Thinking (LSCT) Module achievement, collaborative learning habit, and starting collaborative learning habit. However, students aged 22 to 24 years were more likely than students aged 17-21 to have better critical participation behavior.

Tabel 2 shows that students who had good critical participation behavior and who had fair critical participa- tion behavior were similarly distributed with respect to involvement in student organizations in-campus, positions in off-campus organizations, or had ever had any leadership training.

On the other side, those who had any committee positions or involvement in off-campus organizations were more likely to have good critical participation behavior

The final model (Table 3) shows that the period of involvement with PBL programs, as well as involvement in off-campus organizations, were dominant risk factors for good critical participation behavior. Students who had longer periods of involvement in PBL and involvement in off-campus organizations had a greater tendency to be good critical participators. Students who had involvement in off-campus organizations had a $75 \%$ increase in good critical participation behavior.

Table 1. Some demographic characteristic of subjects and risk of good critical participation behavior

\begin{tabular}{|c|c|c|c|c|c|c|c|}
\hline & \multicolumn{4}{|c|}{$\begin{array}{l}\text { Critical participation } \\
\text { behavior }\end{array}$} & \multirow{3}{*}{$\begin{array}{l}\text { Crude } \\
\text { relative } \\
\text { risk }\end{array}$} & \multirow{3}{*}{$\begin{array}{l}95 \% \\
\text { confidence } \\
\text { interval }\end{array}$} & \multirow{3}{*}{$\mathrm{P}$} \\
\hline & \multicolumn{2}{|c|}{$\begin{array}{c}\text { Fair } \\
(\mathrm{n}=229)\end{array}$} & \multicolumn{2}{|c|}{$\begin{array}{c}\text { Good } \\
(\mathrm{n}=158)\end{array}$} & & & \\
\hline & $\mathrm{n}$ & $\%$ & $\mathrm{n}$ & $\%$ & & & \\
\hline \multicolumn{8}{|l|}{ Gender } \\
\hline Male & 66 & 56.9 & 50 & 43.1 & 1.00 & Reference & \\
\hline Female & 163 & 59.9 & 109 & 40.1 & 0.88 & $0.62-1.26$ & 0.486 \\
\hline \multicolumn{8}{|l|}{ Age } \\
\hline $17-21$ & 214 & 60.5 & 140 & 39.6 & 1.00 & Reference & \\
\hline $22-24$ & 15 & 44.1 & 19 & 55.9 & 1.52 & $0.93-2.46$ & 0.092 \\
\hline \multicolumn{8}{|l|}{$\begin{array}{l}\text { Achievement on LSCT } \\
\text { module }\end{array}$} \\
\hline Failed & 6 & 54.6 & 5 & 45.5 & 1.00 & Reference & \\
\hline Fair & 16 & 59.3 & 11 & 40.7 & 1.22 & $0.34-4.38$ & 0.766 \\
\hline Good & 157 & 61.6 & 98 & 38.4 & 1.02 & $0.32-3.24$ & 0.972 \\
\hline Excellent & 50 & 52.6 & 45 & 47.4 & 1.50 & $0.47-4.83$ & 0.495 \\
\hline \multicolumn{8}{|l|}{$\begin{array}{l}\text { Collaborative learning } \\
\text { habit }\end{array}$} \\
\hline Never & 81 & 65.9 & 42 & 34.2 & 1.00 & Reference & \\
\hline $1-3$ times per week & 145 & 56.2 & 113 & 43.8 & 1.18 & $0.82-1.72$ & 0.374 \\
\hline$\geq 4$ times per week & 3 & 42.9 & 4 & 57.1 & 1.74 & $0.54-5.62$ & 0.356 \\
\hline \multicolumn{8}{|l|}{$\begin{array}{l}\text { Starting collaborative } \\
\text { learning habit }\end{array}$} \\
\hline Never & 64 & 69.6 & 28 & 30.4 & 1.00 & Reference & \\
\hline Few months. & 20 & 71.4 & 8 & 28.6 & 0.97 & $0.40-2.37$ & 0.962 \\
\hline Medical school & 55 & 67.9 & 26 & 32.1 & 1.03 & $0.59-1.77$ & 0.912 \\
\hline Senior high school & 90 & 48.1 & 97 & 51.9 & 1.58 & $1.09-2.46$ & 0.044 \\
\hline
\end{tabular}


Table 2. Some experiences in organization and risk factors good critical participation behavior

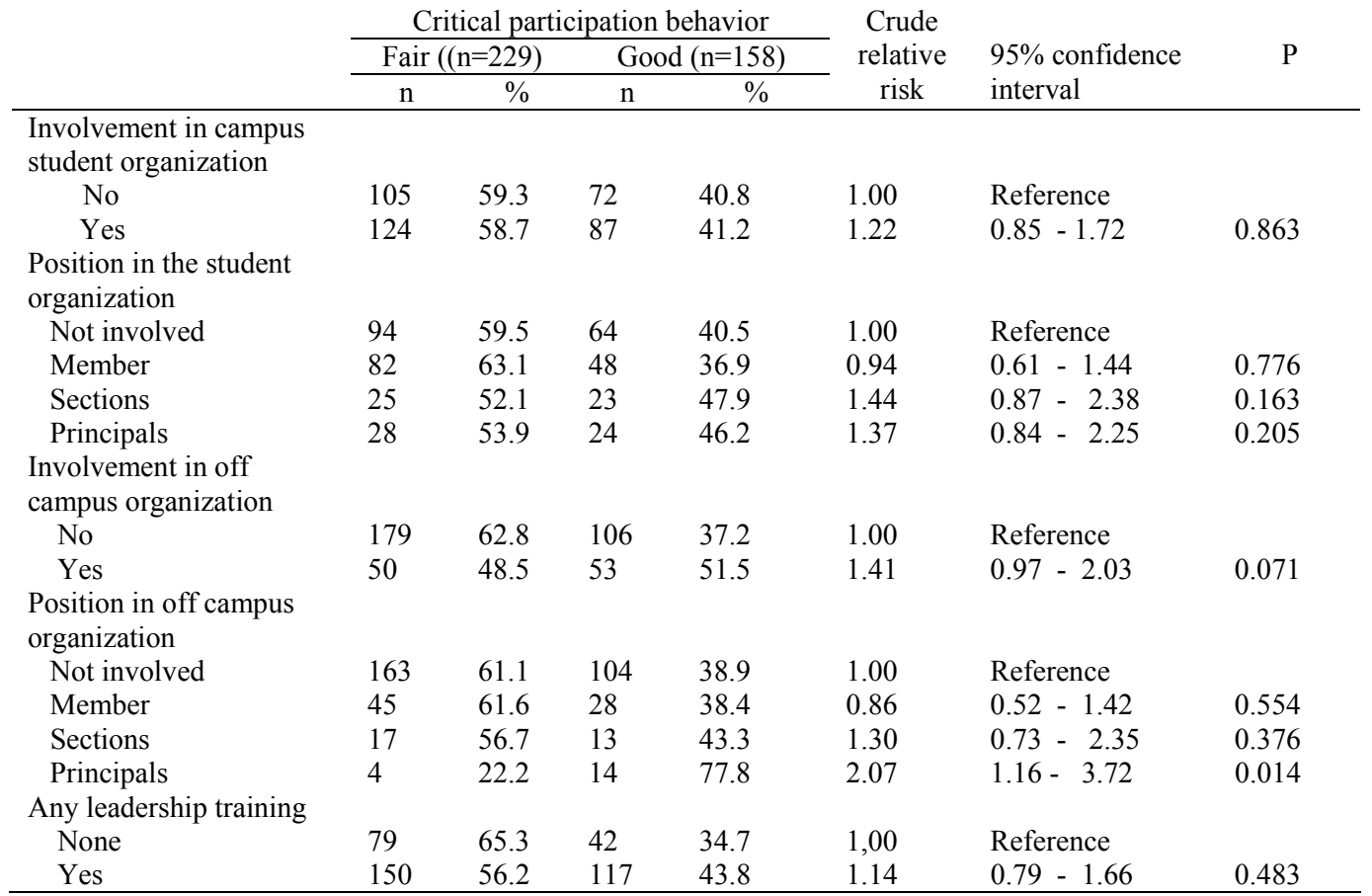

Table 3. Relationship among the risk factors and good critical participation behavior

\begin{tabular}{|c|c|c|c|c|c|c|c|}
\hline & \multicolumn{4}{|c|}{ Critical participation behavior } & \multirow{3}{*}{$\begin{array}{c}\text { Adjusted } \\
\text { relative } \\
\text { risk }\end{array}$} & \multirow{3}{*}{$\begin{array}{l}95 \% \\
\text { confidence } \\
\text { interval }\end{array}$} & \multirow{3}{*}{$\mathrm{P}$} \\
\hline & \multicolumn{2}{|c|}{ Fair $(n=229)$} & \multicolumn{2}{|c|}{ Good $(n=158)$} & & & \\
\hline & $\mathrm{n}$ & $\%$ & $\mathrm{n}$ & $\%$ & & & \\
\hline \multicolumn{8}{|c|}{$\begin{array}{l}\text { Duration of involvement } \\
\text { in PBL curriculum }\end{array}$} \\
\hline 1 years & 106 & 67.9 & 50 & 32.1 & 1.00 & Reference & \\
\hline 2 years & 57 & 56.4 & 44 & 43.6 & 2.07 & $1.37-3.14$ & 0.001 \\
\hline 3 years & 66 & 50.3 & 65 & 49.6 & 2.33 & $1.55-3.49$ & 0.000 \\
\hline \multicolumn{8}{|c|}{$\begin{array}{l}\text { Involvement in off- } \\
\text { campus organization }\end{array}$} \\
\hline No & 179 & 62.8 & 106 & 37.2 & 1.00 & Reference & \\
\hline Yes & 50 & 48.5 & 53 & 51.5 & 1.75 & $0.99-3.11$ & 0.050 \\
\hline
\end{tabular}

* Adjusted each other among variables listed on this table, age, starting collaborative learning habits

\section{DISCUSSION}

$64.6 \%$ of the medical students took part in this study. Their absence in this study, among other reasons, was due to their non attendance at the examinations where the data were collected and some of the students openly expressed their refusal to participate in the study, based on reasons such as conflicts with other business activities or need to take another examination.
There are several limitations that must be considered in interpreting these study results. The data of behavior would be much more valuable if it was obtained using the observation method rather than using questionnaires. Students should do self reflection when they do EMI: critical thinking disposition assessment. Therefore, maturity might influence the quality of students' answers to the assessment. However, the assessment used in this study was a simple method which consisted of 12 closed questions only. This method met all the re- 
quirements needed as instruments used to collect data. All the questions were valid and reliable with a Cronbach alpha of 8.06. This closed questionnaire made it simple and easier to answer. Furthermore, the author guided the students during their filling in of the questionnaires. Another problem was that some students, having just taken examinations, were exhausted.

The results show that the period of involvement in a PBL program was one important risk factor of good critical participation behavior. This indicates that PBL not only develops students' high order thinking skill but also enhances students' critical participation behavior. Walker's study reported that students who had a PBL approach and integrated curriculum had better critical thinking skills. PBL which teaches students to carry out discussions, questioning techniques, debate, professionalism, self-directed learning and collaborative learning is basically a good method to improve students' critical thinking skills, as well as critical participation behaviors. ${ }^{9}$ It is believed to be an appropriate approach to prepare students to become good medical doctors. Scoot et al reported that critical thinking skills and dispositions, including critical participation or engagement, will develop during the preclinical program and will influence students' performance during their study in clinical clerkship and their medical practice. ${ }^{10}$ As critical thinking skills and disposition are developing during their study time in the PBL approach, it is explicable if the findings of this study indicate that the longer the students are involved with the PBL approach, the better their critical participation behavior is. Therefore critical participation behavior is considered as a disposition which developed significantly, and not the one which remained unchanged. ${ }^{6}$

Maturity seems to be the risk factor of good critical participation behavior. This study noted that students aged 22-24 years were $40 \%$ more likely to have good critical thinking behavior compared to those aged 17-21 years. This may be due to cognitive maturity which plays an important role in this issue. ${ }^{11}$ Ricketts' study reported that age and gender were predictors of sub-skill analytical skills, but it was not reported that age might become a risk factor of critical participation behavior. ${ }^{4}$

Our findings reveal that the longer the period of conducting collaborative learning results in a better performance of critical participation behavior. This finding is similar with the Rimiene's study finding ${ }^{12}$ that cooperative learning influenced critical thinking skill and disposition, including critical participation. In addition, the other study by Welch et al also reported that based on her action research she proved that collaborative learning was an important activity to critically solve patients' and a community's problems using an evidence-based approach. She added that collaboration in solving the problems would develop greater understanding and enhance empathy. ${ }^{13}$

Rickettes' study also indicated that grade point average (GPA) was a predictor of some sub-skill of critical thinking skills and disposition. He suggested evaluating the effect of a specific school's subject or course which teaches critical thinking skills. ${ }^{4}$ In Sultan Agung Medical Faculty, critical thinking is taught together with learning skills in a module named Learning Skill and Critical Thinking (LSCT), which is the first module of the preclinical program. This study shows that students' achievement scores in that module did not seem to be the dominant risk factor for critical participation behavior. This might be due to the fact the achievement score was not only the score of the critical thinking course, but also the score of the learning skill course, which might cause bias in this study.

Gender was not predictor of critical thinking behavior. This finding is similar with Facione's study. ${ }^{14}$ However, it is different from Rickettes's study, ${ }^{4}$ which reported that gender was a predictor of critical thinking disposition, including critical participation. Furthermore this study ${ }^{4}$ also explained that culture and customs seemed to influence the gender issue. Therefore, in his report, he suggested conducting focus studies to investigate the relationship of gender with critical thinking skill and disposition, including critical participation.

Learning strategy and out-class or extra-curricular activities give positive effect to students' critical thinking skills and disposition. ${ }^{3}$ Zaff's study suggested that consistent participation in extracurricular activities from 8th grade through 12th grade predicts academic achievement and pro-social behaviors in young adulthood. ${ }^{15}$ Similar with these findings, my findings indicated that students who were actively engaged in any organizational activities might exhibit better critical participation behavior. Students' activities in students' organizations, as well as off- campus organizations, give them experiences in taking part in the solving of other people's and a community's problems. They also strengthened concern and empathy during their collaborative activities in organizations.

In conclusion, students who had spent a longer time studying using a PBL curriculum and were involved in off-campus organizational activities had better critical participation behavior. 


\section{REFERENCE}

1. Indonesian Medical Council. Standar Kompetensi Dokter Indonesia. Jakarta. The Council; 2005.

2. Philiphs V, Bond C. Undergraduates' experiences of critical thinking. Higher Education Research and Development. 2004;23:277-94.

3. Dam G. Volman M. Critical thinking as a citizenship competence: teaching strategies. Learning and Instruction. 2004;14:359-79.

4. Ricketts J. The efficacy of leadership development, critical thinking dispositions, and student academic performance on the critical thinking skills of selected youth leaders [Thesis]. Florida. Univ Florida. 2003.

5. Diestler S. Becoming a critical thinker.5th ed. New Jersey. Pearson Education, Inc. 2005.

6. Rimiene V. Assessing and developing students' critical thinking. Psychol Learning \&Teaching..2002;2:17-22.

7. Barros AJD, Hirakata VN. Alternative for logistic regression in cross-sectional studies: an empirical comparison of models that directly estimates the prevalence ratio. BMC Medical Research Method. 2003; 3 (21). Downloaded from: http//www.biomedcentral.com/1471-2288/3/21.
8. Hosmer DW, Lemeshow S. Applied logistic regression. 2nd ed. New York: John Willey \& Sons; 2000.

9. Walker SE. Active learning strategies to promote critical thinking. Journal of Athletic Training. 2003; 38:263-7

10. Scoot J, Markert RJ, Dunn M. Critical thinking: change during medical school and relationship to performance in clinical clerkship. Medical Education Journal, 1998, 32, 14-18

11. Facione P, Giancarlo C, Facione N, Gainen J. The disposition toward critical thinking. J General Educ. 1995;4:1-25.

12. Rimiene V. Cooperative learning influence on students' critical thinking. Educational reform and teachers' training. Scientific works. 1999;5:144-7.

13. Welch A, Pamela D. Closing the gap: collaborative learning as a strategy to embed evidence within occupational therapy practice. J Eval in Clin Practice 2006; 12: 227-8.

14. Facione PA, Facione NC, Giancarlo CA, The motivation to think in working and learning. In Jones Editor. Preparing competent college graduates: setting new and higher expectations for student learning. San Francisco. Jossey-Bass Publishers 1997. 67-79.

15. Zaff JA, Moore KA, Papillo AR, Williams S. Implications of Extracurricular Activity Participation During Adolescence on Positive Outcomes. J Adolescent Research.2003;18:599-630 